bility of abuse exists in the workings of the former practices, but whether the artificial compromise developed as a curative will relieve or only aggravate the evils inherent in the distribution system can be known only after the new procedures have had a fair trial. It may be that the "blocks of five" and "trade showing" will have to be abandoned, and new procedures devised in the light of future experience.

\title{
A RE-EXAMINATION OF COMPETITION IN GAS AND ELECTRIC UTILITIES
}

Monopoly is unquestionably the prevailing mode of utility operation. Its extensive use, however, has not always been accompanied by widespread popularity among consumers of gas and electricity. Perennial agitation for municipal ownership and for better regulation is indicative of the vealnnesses in the current utility order. Usually the dissatisfied customer who seeks better service at lower rates is individually incapable of exerting effective pressure for reform. Hence, the consumer must rely in large measure on the wisdom, vigilance, and power of the state regulatory commissions. It is extremely important, therefore, that the commissions utilize every weapon in their regulatory arsenals to improve the condition of the consumers. One of these weapons which may under certain circumstances be a constructive and friendly ally of regulation is competition between utilities. In fact, prior to the turn of the century, there was scarcely a city in the country which did not permit competition as a device of control. ${ }^{1}$ But today the great majority of commissions use their statutory powers to prevent the existence of competition. This hostile attitude toward competition dates back approximately to 1900 when monopoly was supplanting competition in public utilities. Once aware of the justification and reasons for shifting from competition to monopoly, one can determine whether the events of the last thirty years have altered the force of those reasons. Furthermore, if the justification for monopoly is still sound in theory but has failed in practice, alternative methods of operation deserve greater attention.

The major support for originally changing to monopoly was found in three primary sources. First, competition was too costly. What began as rivalry and spirited competition was frequently transformed into the cut-throat variety. This led to financial exhaustion of weaker competitors which, in turn, resulted in consolidations or agreements as to rates or territory. The public paid for this evanescent competition in high rates, attendant upon large rate bases, inflated mergers, and watered stock. ${ }^{2}$ Unfortunately, only slight relief could

1. Bening, Cospetition and Mfonopoly in Public Utility Indistales (1938) 19.

2. Id. at 20 . 
be obtained from the static, discontinuous control of utilities by charters and franchises. ${ }^{3}$ Secondly, a superior type of regulatory mechanism made its appearance about 1905 in the form of state utility commissions. ${ }^{4}$ The existence of the commission as a regulator and guardian of the interest of the consumer provided a basis for the public to sanction monopoly in utilities although competition was generally preferred in American industry. ${ }^{5}$

In the third place, monopoly was said to have intrinsic superiority as compared with the destructive effects of competition. An engineering advantage arises from the nature of the physical plant and equipment. Since there is a marked predominance of fixed over variable costs in utility operation, a tendency exists for unit cost to decrease as the amount of business increases. ${ }^{0}$ By reason of the economies of large scale production, it may be said that the greater the density of service within a compact area, the more economical the distribution. ${ }^{7}$ Then, too, since not all consumers use the service for the same purpose, their time of use will not exactly coincide, and consequently a greater quantity of service can be rendered with a given amount of production and distribution capacity. ${ }^{8}$ The above three principles, known in utility jargon as decreasing cost, density factor, and diversity factor, all underline the importance of serving the largest possible number of users. Conversely, these enumerated benefits of monopoly tend to disappear when competition divides the consumers into two groups. Furthermore, if one distribution system is sufficient, a second constitutes an economic waste insofar as there is duplication of facilities. ${ }^{9}$

Fortified not only by these theoretical advantages, but also with a fresh recollection of the excesses of competition and its aftermath, the utilities have led the country to take regulated private monopoly for granted. Economists ${ }^{10}$ as well as utility executives ${ }^{11}$ have said that people must realize that enterprises supplying gas and electricity are "inherently" or "naturally" monopolistic. Since these monopolies are "natural," and since nature is beneficent,

3. Jones and Bigham, Princtples of Public Utilities (1931) 102 et seq. Wilson, Herring and Eutsler, Public Utility Regulation (1938) 26.

4. Mosher and Crawford, Public Utility Regulation (1933) 20-26.

5. Bonbright, Public Utilities and the National Power Policies (1940) 4-8.

6. Benling, op. cit. supra note 1 , at 29 . Recent cost studies indicate that the decreasing cost principle has less validity in railroads than was formerly assumed. Sce Healy, The Economics of Transportation in America (1940) 192-198. Moreover, economic monopoly does not insure generating units of optimum size.

7. Benling, op. cit. supra note 1 , at 30 .

8. Id. at 32. See Mortenson, Legal Possibilitics and Limitations of Milk Distribution as a Public Utility (1939) 15 J. LAND \& P. U. Econ. 438.

9. Myers, Competition in the Public Utility Industry (1926) 45 J. ELECT. 310.

10. Brown, The Gas Light Company of Baltimore-A Study of Natural MloNopoly (1936) 63; JoNes AND BIGHAMr, op. cit. supra note 3, at 67 ("inevitable conclusion").

11. Insull, The Necessity for Monopolistic Nature of Public Utilitics (1923) 10 N. E. L. A. Bull. 707. 
the inference is that they are "good" monopolies. 12 Any conflict of interest between the private monopoly and the public, it is argued, should be reconciled by regulatory commissions. ${ }^{13}$

While many have been resigned to the notion of "natural monopoly," the sanctity of the concept has not gone unchallenged. In fact, during the past thirty years there have been at least 120 reported cases in which the desirability of competition in gas and electricity has been in issue before a state commission. Only recently the Arkansas Commission allowed one private natural gas company to invade the territory of another. ${ }^{14}$ The decision received general public approval ${ }^{15}$ and had the effect of forcing down rates throughout the state. ${ }^{16}$ Since the fifteen year old natural gas industry, valued at $\$ 3,000,000,000$, has not reached the boundaries of its expansion, ${ }^{17}$ it is likely that the question of competition will continue to arise. Lilkewise, the issue will be debated in the electric light and power industry which is also still expanding. In electricity, cities like Cleveland and St. Louis ${ }^{18}$ have not found competition unacceptable. In Seattle, consumers have a choice of two electrical services, yet the theoretical wastes of duplication have not prevented their rates from being at least as low as any city of comparable size.

Protest against private monopoly has also been manifested by the introduction of government ownership. But those who look to public ownership as the means of obtaining better service at lower rates may be reminded that gas utilities are still almost completely private ${ }^{10}$ and that only about seven per cent of our electricity is publicly furnished. ${ }^{20}$ Whoever is impatient with the slow increase in public ownership, or whoever dislikes government owner-

12. Gray, The Passing of the Public Utility Concept (1940) $16 \mathrm{~J}$. Lasd \& P. U. ECON. 8.

13. Myers, loc. cit. supra note 9.

14. Louisiana Nevada Transit Co., 32 P. U. R. (N.s.) 219 (Ark 1939), aff'd, 142 S. W. (2d) 1940 (Ark. 1940). Hereafter, unless the contrary is indicated, a citation to the Public Utility Reports will mean a decision of the state utility commission. For the decision of the Federal Power Commission in this case, see 30 P. U. R. (2r.s.) 40 (1939).

15. Communication to the Yale Lay Journal from the Arkansas Department of Public Utilities, Nov. 13, 1940.

16. Note (1940) 26 P. U. Forr. 179.

17. Hearings before Subcommittee of the Committec on Interstatc and Forcign Commerce on H. R. 11662, 74th Cong., 2d Sess. (1933) 4S; Natural Gas (August, 1940) 22 FORTUNe 56.

18. State ex rel. Union Elec. Light \& Power Co. v. Public Service Comm., 333 MIo. $426,62 \mathrm{~S}$.W. (2d) 742 (1933). In this case the state supreme court handed down a well-reasoned opinion in support of preserving regulated competition in St. Louis. Also see Unnion Electric Light \& Power Co., P. U. R. 1932E 402 (MO.).

19. Bauer, Public Ownership of Public Utilities in the U. S. (1939) 201 Axziss 50.

20. Ibid. Mr. Wendell Willkie expressed the belief that public ownership would not supplant private utilities. If it would occur, however, it would be about twenty years in the future. See Hearings before the Joint Committee on the Temessec Valley Authority on P. R. 83, 75th Cong., 3d Sess. (1939) 4350. 
ship but is dissatisfied with private monopoly, may at least consider an unduly neglected ${ }^{21}$ alternative - regulated competition.

The new foundations of regulated competition are enmeshed in a re-examination of the hallowed theory of "natural" monopoly. It is believed that the assumptions under which private monopoly would succeed have often collapsed. Yet, concurrently, a new basis for competition has been established which not only avoids most of the early competitive pitfalls in utility operation, but also offers the well-known advantages of competition. Support for these generalizations can be found in a critical study of the current utility scene.

In surveying the present system few will deny that the keystone in the arch of regulated monopoly has always been the state commission. In spite of all the theoretical benefits of monopoly, it has been a popular and settled conviction that private monopoly could only be reconciled with the public interest by the alchemy of public regulation. ${ }^{22}$ Yet, at the outset, the role of the commission was made almost entirely negative; its interference was largely confined to preventing excessive charges and patent discriminations. ${ }^{23}$ Coupled with this negativistic philosophy of control are at least three major reasons why commission regulation is inadequate. In the first place, insufficiency of authority is a common ailment. For example, in five states, the public service commissions have no jurisdiction over gas and electric utilities. ${ }^{\mathbf{2 4}}$ The Uniform Public Utilities Act, providing for more stringent regulation, ${ }^{25}$ is still far from general adoption although some progress in strengthening the commissions has been made in the last ten years. ${ }^{20}$ Secondly, all the necessary legislative power may not result in increased effectiveness, if the personnel of the commissions is utility-minded and politically influenced. Moreover, since commissioners generally receive low salaries and are subject to rapid

21. Hall, Regulation of Public Utilitics (1939) 206 ANNALs 92, 94. In discussing the various methods of dealing with utilities there is no suggestion of competition as an aid to regulation.

22. "To allow the great monopoly industries to remain without control in private hands is to allow an imperium in impero-nothing less than a plutocracy." 2 Tuussig, Principles of Economics (3d ed. 1921) 433. Also see Gray, loc. cit. supra note 12. Patents are probably the only important exclusive monopolies which are not directly regulated.

23. The traditional policy of negative restraint is strikingly emphasized by a recently compiled list of what the public utilities are not forced to do for the positive promotion of public welfare. See Gray, supra note 12, at 16. Also see statement of Mr. Jerome Frank in Hearings before the Temporary National Economic Committee on $P . R .113,76$ th Cong., 1st Sess. (1939) 1954.

24. Weich, Cases on Public Utility Regulation (2d ed. 1940 Supp.) 120; Mosher, Defects of State Regulation of Public Utilities in the U. S. (1939) 201 ANnats 105.

25. Wruson, HERRING AND EUTSLER, op. cit. supra note 3, at 52.

26. Bacharach, The Powers of State Utility Commissions (1940) 26 P. U. Four. 627. See also Proceedings of the National Association of Railroad and Utilities COMMISSIONERS (1936) 361. 
turnover, the quality and continuity of regulation is seriously impaired." The lure of permanent positions with private utilities is likewise a frequent deterrent to effective enforcement. Finally, it has been said that not a single commission is adequately financed to carry on the broad range of duties prescribed in the law. ${ }^{28}$ When the total annual appropriation for forty-seven commissions is only $\$ 7,113,851$ with $\$ 2,147,771$ of the total spent by three states,"=- it should occasion no surprise that investigations are infrequent and that regulation is spasmodic. In fact, complicated rate structures, insufticient cost data, and the "fair value" quandary would tax any commission personnel even assuming a generous legislature. ${ }^{30}$ Therefore, in view of these serious deficiencies in commission regulation, competition should not be summarily dismissed. It may be that regulated competition will create an incentive for better utility operation which no commission, however attentive, can hope to supply. ${ }^{31}$

In addition to the general breakdown of regulation, there are more affirmative reasons for allowing competition. Paradoxical as it may seem, it is nonetheless true that the commissions are now frequently in a position to eliminate many of the old objections to competition which arose out of the pre-commission excesses. One of these was the fear of rate wars and ruinous competition. But this fear should subside now that the Supreme Court has made it clear that the commissions can constitutionally fix minimum as well as maximum rates. ${ }^{32} \mathrm{~A}$ second objection was that low rates growing out of competition boomerang when eventual consolidation produces a doubly large rate base and hence high rates. ${ }^{33}$ This argument has lost much of its force, however, now that thirty-seven states have varying degrees of control over consolidations and mergers, ${ }^{34}$ implemented in thirty-three states by statutory authority over capitalization and issue of securities. ${ }^{35}$ In addition, both the

27. Behling, op. cit. supra note 1, at 165; Wilson, Herrang a:s Eutsles, op. cit. supra note 3 , at 63 ; Mosher, loc. cit. supra note 24 .

28. Mosher, loc. cit. supra note 24.

29. Ibid. Compare 2 Lyon, Abraurson and Assoctates, Governusest ano EcososIC LIFE (1939) 660f.

30. Justices of the Supreme Court have referred to the inadequacy of state regulation. See McCart v. Indianapolis Water Co., 302 U. S. 419,435 (1938); St. Joseph Stockyards Co. v. United States, 298 U. S. 38, 88 (1936).

31. Lake, Competition in the Public Utility Ficlds (1938) 10 Mrss. L. J. 197.

32. Public Serv. Comm. v. Great Northern Util. Co., 289 U. S. 130 (1933) (private competition); City of Seymour v. Texas Elect. Serv. Co., 66 F. (2d) 814 (C. C. A. 5th, 1933), cert. derried, 290 U. S. 685 (1933) (municipal competition). For conscious recognition of the change which regulation has effected see Idaho L. \& P. Co., P. U. R. 1915A 2(Idaho). See also Lake, loc. cit. sipra note 31.

33. Gray, L. R., Public Utility Competition: A Case Study (1939) 15 J. Lnutd \& P. U. Econ. 195.

34. Moody's Public Utilities (1939) a 90 (Bonbright Utility Regulation Chart).

35. Ibid. Also see Wilson, Herring and Eutsleb, op. cit. sipra note 3, at 229; Barnes, Public Utility Control in Misssachusetts (1930) 20. 
Federal Power Commission ${ }^{36}$ and the Securities and Exchange Commission ${ }^{37}$ provide a potent regulatory restraint. Furthermore, the history of utility regulation suggests that it is easier for a commission to check the abuses of competition than to impose positive duties on a private monopoly. ${ }^{38}$

Further objections to the use of competition can be met by a consideration of the diverse forms which competition assumes. Critics of competition and commissions have sometimes failed to examine the extent and nature of the competition at issue. ${ }^{39}$ In the main, the concept can be broken down into three varieties, ${ }^{40}$ which sometime overlap: competition of duplication, area, and displacement. In the first type, the consumer has a choice of buying his gas or electric service from one of two companies. ${ }^{41}$ Irrespective of the consequent wastes of duplication, the consumer may nevertheless fare better than under regulated monopoly; a fortiori, to the extent that there is competition without duplication, the result may be more satisfactory. Even under sideby-side competition the market may be divided so that a competing company will not need the exact same facilities for generation and distribution as if it were a monopoly.

Area competition, by contrast, involves the sharing of a territory between two or more companies. ${ }^{42}$ While it destroys the monopoly position of the original company as to the total area, it may not involve any duplication of facilities. It is a kind of competition which threatens the existing company with a restriction of its possible marketing area. Once a given market territory has been divided between two companies, consumers have a yardstick at hand by which to compare their rates with those prevailing nearby. If an area is not completely served, or if only partial duplication will result, it is questionable if the supposed benefits of integration would offset the advantages of yardstick competition. The third class constitutes a hybrid, for the competition of displacement gives the existing company the option of selling its

36. The Federal Power Act, 49 StAT. 863, 16 U. S. C. \$791 (Supp. 1939) (Parts II and III).

37. Public Utility Holding Company Act, 49 StAT. 838 (1935), 15 U. S. C. $\$ 79$ (Supp. 1939). See Central Illinois E. \& G. Co., Holding Company Act Release No. 1592, June 21, 1939, p. 16; Public Service Co. of Colorado, Holding Company Act Release No. 1701, Aug. 28, 1939, p. 61.

38. Gray, loc. cit. sitpra note 12 .

39. Hyneman, Public Encouragement of Monopoly in the Utility Industrics (1930) 147 Annals 160.

40. There is a fourth kind of direct competition in which the consumer instead of a public utility furnishes its own electricity. In this type of competition, commission intervention is the exception. But see Spingler Electric Corp., P. U. R. $1933 \mathrm{D} 493$ (N. Y.). For discussion see BEHLING, op. cit. supra note 1 , at 96.

41. Wichita Gas Co. v. Public Service Comm., 132 Kan. 459, 295 Pac. 668 (1931); Municipal Gas Co., P. U. R. 1928D 418 (Okla.); Re Eyer, P. U. R. 1926A 140 (Mo.).

42. Central Maine Power Co., P. U. R. 1932C 157 (Me.); St. Lawrence Transmission Co., P. U. R. 1921A 577 (N. Y.). See Hoover, A Utility's Right to Protcction from Improper Competition (1930) 5 P. U. FoRT. 346. 
assets to the applicant at a fair value or remaining in business and accepting competition with another utility. ${ }^{43}$ If the former occurs there is obviously no duplication; if the latter, the situation is the same as the first type. Recognition that there are at least three distinct classes of direct competition should warrant revision in those blanket generalizations which unalterably condemn competition.

Finally, those opposed to competition must take heed of the ability of a competitor to offer cheaper services because of lower cost conditions. Ordinarily the commission allows at least a stated return on the investment; $;^{4-4}$ but one of the most unfortunate features of regulated monopoly is that the utility has no special incentive to lower its costs. ${ }^{15}$ By contrast, one of the outstanding merits of competition is that it normally constitutes an automatic spur to reduce costs. Where extraordinary cost disparities exist, competition may be even more imperative than usual. For example, because of cost differences manufactured gas is often no match for natural gas. ${ }^{10}$ Likewise, a natural gas system can hardly ever be free from the hazards of competition arising from the discovery of new sources of supply closer to the final market. ${ }^{47}$ Similarly, in electricity a comparable situation appears where steam generated power resists the advent of cheaper hydro-electric power. ${ }^{48}$ Therefore, it is apparent that to prevent competition, where extreme difference in cost exists, is to inflict an undue penalty on the consumers.

But to some, the above analysis entirely misrepresents the utilities. They are not monopolies, it is repeatedly urged, but instead are rigorously competitive because of the pervasiveness of substitutions of similar services. ${ }^{20}$ Since electricity is sold under predominantly competitive conditions, it is alleged that any profits are competitive profits. ${ }^{50}$ Admittedly, substitution is active in some industrial power and heating, but a large proportion of utility revenue comes from consumers who have little or no choice, such as domestic users of electricity. ${ }^{51}$ Hence it is inaccurate to speak of competitive profits. Moreover, because the market is part competitive and part monopolistic,

43. $\operatorname{Re}$ Call, P. U. R. 1932D 387 (Wyo.) ; Re Brookville, P. U. R. 1929D 483 (Pa.); Green L. \& P. Co., P. U. R. 1920F 980 (Mo.); cf. Truckee River Power Co., P. U. R. 192SE 83 (Cal.); Farmers E. \& P. Co., P. U. R. 1920D 214 (Cole).

14. WiLson, Herring and Eutsler, ap. cit. sipra note 3, at 154 et scq.

45. It is well to bear in mind the limitations on decreasing costs and the opportunities for padding costs; the latter are especially aided by the maze of intercorporate relationships. See Benling, op. cit. sipra note 1, at 33-49.

46. Santa Maria Gas \& Power Co., 9 Cal. R. C. R. 514 (1916); Peaple's Natural Gas Co., P. U. R. 1915C 696 (Pa.).

47. Louisiana Nevada Transit Co., 32 P. U. R. (N.s.) 219 (Ark. 1939).

48. See Hearings, supra note 20 , at 3834 .

49. Le Boeuf, When a Monopoly is Not a Monopoly (1930) 6 P. U. FonT. 707; Cabot, Public Utility Rate Regulation (1929) 7 H.anv. Br.s. Rev. 257, 415.

50. Ibid.

51. Gray, Competition as a Basis for Electric Light and Pouter Rates (1929) $5 \mathrm{~J}$. LAND \& P. U. ECON. 242. 
effective regulation is all the more important to protect domestic users from discriminatory rates charged to subsidize industrial users. ${ }^{62}$ Furthermore, inter-utility competition is seriously curtailed by the expense and inconvenience to consumers of changing sources of heat or power. ${ }^{83}$ Nor is it easy to dodge the stifling effects on competition between gas and electricity, as a result of interrelated control exemplified by the fact that forty per cent of the revenue of the manufactured gas industry is received by companies which are operated in conjunction with electrical utilities..$^{54}$

Equally as important as competitive elements in natural monopoly are the monopolistic features of the suggested competition. In the economists' language, two utilities serving the same market do not represent pure competition, but regulated duopoly. And under duopoly, it is said, each independent seller has nothing to gain by cutting rates because the other seller will follow suit. Since the result of a cut by either one will decrease his own profits, no one will reduce rates and the result is the same as if there were a monopolistic agreement between them..$^{55}$ These conclusions are, however, neither inviolate nor inevitable. For one thing, the consumer enjoys a substantial reduction in rates at the outset because a commission will require it as a prerequisite to the entrance of another company. ${ }^{50}$ In addition to the initial price cut of the entering utility, the elasticity of demand for gas or electricity, ${ }^{67}$ often overlooked, makes possible an increase in revenue for both companies in spite of a rate reduction. Furthermore, a time lag in the lowering of rates and differentiation in service point away from monopolistic results. Finally, the vigorous utility competition in the past, and the fact that competition reduced railroad rates below the regulated maximums gives assurance that competition will ${ }^{\circ}$ not stagnate. ${ }^{.8}$

But before duopoly can yield any benefits, usually its very existence must first receive the legal sanction of the state commission. That sanction is embodied in the administrative technique known as the "certificate of convenience and necessity." It is the indispensable passport which must be

52. Behling, op. cit. supra note 1 , at 140 . 181.

53. Boatwright, Competition and Electric Rates (1931) 7 J. Land \& P. U. Econ.

54. Behling, op. cit. stepra note 1, at 132; Bullard, Let There Be Free Competition (1938) 21 P. U. FORT. 143. The survival of this composite control is seriously threatened by a recent decision of the Securities and Exchange Commission in which it was held that, except for statutory exceptions, gas and electric properties cannot constitute one integrated system under the Public Utility Holding Company Act of 1935. See Columbia G. \& E. Corp., Holding Company Act Release No. 2477, Jan. 10, 1941.

55. Chamberlin, The Theory of Monopolistic Competition (4th ed. 1939) 48.

56. See cases cited infra note 107.

57. Barnes, Temporary Rates in Utility Regulation (1939) 34 ILz. L. REv. 929.

58. Locklin, Economics of Transportation (rev. ed. 1938) 306, 492. Independence of action is made more certain where one competitor is governmentally owned. See cases cited supra note 18 as examples of how a commission can prevent a lessening in competition. 
obtained to gain admission into the previously monopolized territory of another utility. ${ }^{59}$ The certificate, then, is the objective means of translating the economic arguments for or against regulated competition into practice. Consequently, the function of the commission in granting or denying a certificate to a competitor assumes the utmost importance to consumers, utilities, investors, and the general public.

While the power to grant certificates is not found in each state, the scope is sufficiently broad enough to be of primary significance. In at least thirtythree states, containing over two-thirds of the total population, the legislatures compel prospective competitors in gas and electricity to obtain a certificate of convenience and necessity from the state commission. ${ }^{60}$ And the Natural Gas Act of 1938 endows the Federal Power Commission with similar powers over competition in the interstate transportation of natural gas. ${ }^{01}$

A knowledge of the potentialities of a certificate is a prerequisite to its effective use. The cases do not generally reflect a realization that a certificate is an extremely flexible method of regulation. ${ }^{62}$ It has been said that a certificate is in the nature of a mere license which can be amended or revoked. ${ }^{63}$ In fact, a commission can impose conditions at the time of granting a certificate, such as restricting the extent of competition. ${ }^{\text {Gs }}$ Or since the administrative body is not usually bound by res judicata, it may subsequently

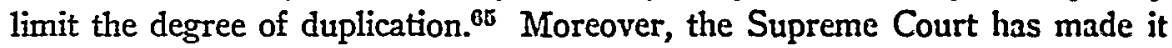
quite clear that a certificate to an existing utility is no insurance against competition. $^{\text {es }}$

Inasmuch as the words "convenience and necessity" are the only standard to which the regulatory body must adhere, ${ }^{67}$ the state commission is also

59. The certificate is also the customary prerequisite to operate where there is no problem of competition.

60. MOODY's, op. cit. supre note 34. This certificate authority does not always apply to municipal plants.

61. 52 Stat. 833 (1938), 15 U. S. C. $\$ 717$ (Supp. 1939). See Kansas Pipe Line and Gas Co., 30 P. U. R. (N.s.) 321 (F. P. C. 1939). See also Gerkin, The Federol Power Commission and the Gas Industry (1939) 150 Axr. Gas J. 9.

62. Unfortunately, the commission decisions, with some exceptions, reveal an ignorance of the policy of other states and a rather blind adherence to the judicial principle of stare decisis. See Hyneman, The Case Law of the New Yorl: Public Service Commission (1934) 34 COL. L. REV. 67, 73.

63. BeHzing, op. cit. supra note 1, at 62; Hall, Cerfificates of Conernience and Necessity (1929) 28 MicH. L. REv. 107, 276.

64. South Coast Gas Co., P. U. R. 1929E 476 (Calii.). But see Arkansas Valley Natural Gas Co., P. U. R. 1931A 415 (Colo.).

65. Vallejo E. L. \& P. Co., P. U. R. 1923A 1 (Calif.).

66. Tennessee Elec. Power Co. v. Tennessee Valley Auth'y, 306 U. S. 118 (1939): Alabama Power Co. v. Ickes, 302 U. S. 464 (1938).

67. There is general agreement that the courts ordinarily will not substitute their judgment for that of the administrative bodies. Federal Communic Comm. $v$. Pottsiille Broadcasting Co., 308 U. S. 422 (1939) ; Kansas G. \& E. Co. v. Public Service Comm., 122 Kan. 462, 251 Pac. 1097 (1927). 
endowed with a wide range of freedom to allow or prevent competition. Rare is the statute which even suggests a definition of these key words. ${ }^{68}$ Certainly, "necessity" is not used in its lexicographical sense to mean "indispensable";09 if it were, no certificate would ever be granted. Rather, the total expression is a vague term of art. Insofar as any over-all theory has been enunciated, it has been held that the primary concern of the commission is the public convenience and need, that the interests of the existing company are secondary, and that the desires and solicitations of the applicant are a relatively minor consideration. ${ }^{70}$ Or it has been stated that there must be a gain to the public welfare large enough to compensate for the loss involved in duplication or displacement of facilities. ${ }^{71}$ To ascertain, however, whether a net gain will ensue from competition of whatever variety, the commission invariably leaves the highly abstract level of "convenience and necessity" and buckles down to a comparison of the utilities in question.

But in making comparisons, the majority of the state commissions place the particular facts over against an interpretation of the statute, which favors monopoly at almost any price. ${ }^{72}$ Although the state statutes were designed to prevent promiscuous competition, they explicitly provided for the entrance of new companies. In practice, the latitude of discretion given the commissions has led to the formulation of major policy by administrative officials instead of by the legislatures. So sharp are the contrasts among states in permitting or denying competition under similar laws that the legislatures may desire more concrete statutes in the future, or present commissioners, not tied by stare decisis, may reverse past commission policy. ${ }^{73}$

Measured by the policy pursued, the state commissions tend to fall into two groups. California leads those which are liberal in allowing competition while New York and Wisconsin are in the forefront of those who make competition the last resort. In 1912, the California Commission frankly admitted its inability to achieve the benefits of competition and saw in the latter a powerful ally of regulation. ${ }^{74}$ With admirable foresight it realized that the incentive to compete would suffer an almost fatal blow if an existing company. could rest secure until a competitor appeared, and then avoid competition by matching the proffered advantages of the applicant. Therefore, contrary to the policy of other states, an existing company was not given a day of repentance, but was compared with the applicant as of the date of

68. For exceptions see Natural Gas Act, 52 S'rAT. 833 (1938), 15 U. S. C. $\$ 717$ (Supp. 1939); Mice. Stat. Ann. (1937) §§ 22, 145.

69. Wabash C. \& W. Ry. v. Commerce Comm., 309 Ill. 412, 141 N. E. 212 (1923).

70. Kansas G. \& E. Co. v. Public Service Comm., 122 Kan. 462, 251 Pac. 1097 (1927).

71. Bemling, op. cit. supra note 1 , at 62 .

72. Hall, supra note 63 , at 283.

73. Metropolitan Edison Co. v. Public Service Comm., 127 Pa. Super. 11, 191 Atl. 678 (1937) ; Borough of Myerstown, 12 P. U. R. (N.s.) 39 (Pa. 1939).

74. Pacific G. \& E. Co., 1 Cal. R. C. R. 203 (1912). 
the application to compete. ${ }^{\text {is }}$ If this traditionally liberal policy of California now shows signs of weakening, ${ }^{78}$ it may be partially justified, at least as to duplicatory competition, by reason of the comparative efficiency and exemplary quality of that state commission. In the larger group of states, the commissions tacitly assume their own effectiveness to deal with private monopoly, and rationalize that a better service can be had in the long run by protecting the initiative of the pioneers in the field. ${ }^{77}$ This reasoning has not been literally followed, however, where area competition was at stake; in such instances, the first company in the area was not allowed to retain a monopoly if it failed to develop part of its original grant of territory. ${ }^{88}$

Once a state commission has decided to allow competition either as a general policy or in a restricted manner, it relies on a number of specific factors to determine each individual application for a certificate. These include service, rates, potential demand, investment, financial strength, and public opinion. ${ }^{79}$ Fundamental to a decision to permit or restrict competition is the adequacy of service. Naturally, where the existing service is satisfactory, the applicant must show defects in other respects to be successful..$^{80}$ By the same token, poor service sows the seeds of competition, ${ }^{81}$ but not invariably. ${ }^{82}$ The strains of national defense priorities ${ }^{83}$ or of company reconstruction, ${ }^{84}$ for example, may be a valid excuse for inferior service. On the other hand, it is not always enough to render efficient and cheap

75. Pacific G. \& E. Co., 1 Cal. R. C. R. 203 (1912); Oro Electric Corp., 2 Cal. R. C. R. 748 (1913) ; Pacific G. \& E. Co., P. U. R. 1922B 495 (Calif.) ; Truckee River Power Co., P. U. R. 1928E 83 (Calif.). Followed in other states: Idaho L. \& P. Co., P. U. R. 1915A 2 (Idaho) ; Farmers E. \& P. Co., P. U. R. 1920D 214 (Colo.).

76. Western Natural Gas Co., P. U. R. 1930A 307 (Calif.). Communication to the Yale Law Journal from the California Commission, Dec. 4, 1940.

77. Illinois P. \& L. Corp. v. Commerce Comm., 320 Ill. 427, 151 N. E. 236 (1926); Central Maine Power Co., P. U. R. 1930A 513 (Mfe.); Carey Electric \& Mfilling Co., P. U. R. $1926 \mathrm{D} 804$ (Wis.) ; Lawrence Park H. L. \& P. Co., P. U. R. $1926 \mathrm{~B} 111,125$ (N. Y.) ; $R e$ Vineland, P. U. R. $1926 \mathrm{D} 723$ (N. J.) ; $R e$ Tootell, P. U. R. 1927 A 155 (N. H.).

78. Nassau \& Suffolk Lighting Co., P. U. R. 1927 A 132 (N. Y.); Central Mfaine Power Co., P. U. R. 1932 C 157 (Me.) ; Colliers L. H. \& P. Co., P. U. R. $1916 C 212$ (N. Y.).

79. The decisions of the Arkansas, California, and Missouri Commissions, as well as those of the Federal Power Commission, are usually conspicuous by the clarity and completeness with which these tests are applied.

80. Jackson County L. H. \& P. Co., 16 P. U. R. (N.S.) 244 (Afo. 1936); Mrunicipal Gas Co., P. U. R. $1928 \mathrm{D} 418$ (Okla.); Independence Natural Gas Co., P. U. R. 1923D 433 (Mo.).

81. Re Call, P. U. R. 1932D 387 (Wyo.); Raytown Chamber of Commerce, 17 Mo. P. S. C. R. 601 (1929); Truckee River Power Co., P. U. R. 1928E 83 (Calif.); Re Eyer, P. U. R. 1926A 140 (Mo.).

82. Re Brookville, P. U. R. 1929D 483 (Pa.); Aridvalley Power Co., P. U. R. 1916A 959 (Pa.).

83. Glen Mfills Electric Co., P. U. R. 1920B 797 ( $\mathrm{Pa}$.$) .$

84. Oro Electric Corp., 2 Cal. R. C. R. 748 (1913). 
service to those already being served; for a utility is also judged by the way it tries to serve those who are not yet customers. ${ }^{85}$ Thus, a premium is placed on willingness ${ }^{86}$ and promptness ${ }^{87}$ to serve as well as on the physical ability to render service. The fact that the commission could compel service through time-consuming legal processes does not prevent the regulatory body from employing competition as the remedy, especially where the utility has a reputation for being exhaustingly litigious. ${ }^{88}$ Where there is an emergency, speed is even more essential. ${ }^{80}$

The commission, however, does not concentrate exclusively on the existing company, but constantly compares it with the applicant's capacity to furnish good service. If the newcomer can render adequate service much more economically because of geographical advantages, the competition may be allowed, but only so long as it does not result in skimming the cream of consumers. ${ }^{90}$ In estimating the reliability of the applicant's claims, the promises may be evaluated in the light of past performances in other localities. ${ }^{91}$

Other significant problems of service arise which are peculiar to natural gas. As the commission looks to the supply of water of a hydro-electric power company, ${ }^{92}$ so must it likewise check on the presence ${ }^{03}$ or absence ${ }^{04}$ of adequate gas reserves of a natural gas company seeking to compete with a similar gas or with the manufactured product. Doubt as to the newcomer's supply of gas has been resolved in his favor on the theory that competitive-minded citizens should bear the responsibility of a possible future cessation in service. 00 Once the basic source is assured, the safety of the gas must also be approved..$^{96}$ Then, too, the size of the pipe line and the pressure within it must

85. Wichita Gas Co. v. Public Service Comm., 132 Kan. 459, 295 Pac. 668 (1931); Pacific G. \& E., P. U. R. 1922B 495 (Calif.).

86. Municipal L. \& P. Co., 12 P. U. R. (N.s.) 103 (Ark. 1935) ; Gas Fuel Service Co., 3 P. U. R. (N.s.) 55 (Calif. 1933) ; Coast Counties G. \& E. Co., P. U. R. 1917C 709 (Calif.) ; Atlantic City Electric Co., P. U. R. 1928D 407 (N. J.).

87. St. Joseph R. L. H. \& P. Co., P. U. R. 1933A 405 (Mo.); Cold Spring L. H. \& P. Co., P. U. R. 1925D 311 (N. Y.).

88. Village of Little Valley, 22 P. U. R. (N.s.) 63 (N. Y. 1938).

89. Re Pinedale, P. U. R. 1932D 96 (Wyo.); Oliver Power Co., P. U. R. 1932C 203 (Colo.).

90. Incorporators of Service Gas Co. v. Public Service Comm., 126 Pa. Super. 381, 190 Atl. 653 (1937) ; Coast Counties G. \& E., P. U. R. 1917C 709 (Calif.); Great Western Power Co., 8 Cal. R. C. R. 426 (1915).

91. Oro Electric Corp., 2 Cal. R. C. R. 748 (1913).

92. Re Call, P. U. R. 1932D 387 (Wyo.).

93. Louisiana Nevada Transit Co., 32 P. U. R. (N.s.) 219 (Ark. 1939); Colorado Gas \& Oil Pipe Line Co., P. U. R. 1925A 499 (Colo.).

94. Incorporators of Service Gas Co. v. Public Service Comm., 126 Pa. Super. 381, 190 Atl. 653 (1937); Jackson County L. H. \& P. Co., 16 P. U. R. (N.s.) 244 (Mo. 1936).

95. Municipal Gas Co., P. U. R. 1928D 418 (Okla.).

96. Louisiana Nevada Transit Co., 32 P. U. R. (N.s.) 219 (Ark. 1939). 
satisfy the commission that the peak load can be met.0i A closely related problem arises out of "shut-off" clauses, which provide that in case of shortage, domestic consumers of natural gas take priority over industrial users. In order to make a long distance pipe line profitable, the low return on the sale of natural gas to industrials usually necessitates the serving of domestic consumers. But during the summer, the great drop in cooking and heating almost forces natural gas companies to sell their product to industry at dump prices to avoid waste. In view of the seasonal nature of the domestic demand and the associated problem of storage, ${ }^{98}$ the commissions have been more or less hostile to applicants who desired to serve only industrials. ${ }^{09}$ New methods of liquifying gas may go a long way, however, toward solving these storage and shut-off problems. ${ }^{100}$ Or commissions may sidestep the entire problem by stating that the competing company will provide what amounts to a new and distinct service. ${ }^{101}$ This teclnnique is also used, with more justification, in holding that because natural gas generally contains about twice as many heating units as artificial gas, the former is a much different service. ${ }^{102}$

Although the gas or electric service may be adequate, the stumbling block to retaining a monopoly may be high rates. ${ }^{103}$ When the rates of the old gas company are so high that other fuels are being widely used, and the consumption decreases as the population of the area increases, then direct competition probably can not be effectively resisted. ${ }^{104}$ If rates of an extravagant electric company are higher by thirty or forty per cent than in comparable communities, competition may be admitted even though the rate of return on the capital invested is fair. In so holding, the Wisconsin Commission indicated the value of the competitive threat in protecting consumers from uneconomical utility expenditures. ${ }^{105}$ Another opportunity for cost control through competition occurs when the state lacks jurisdiction over the rates at which the distributing company purchases for resale. ${ }^{100}$ Usually, excessive

97. Ibid. Kansas Pipe Line \& Gas Co., 30 P. U. R. (x.s.) 321 (F. P. C. 1939).

98. Hearings before the Committec on Interstate Commerce on $S .1725,74$ th Cong., ist Sess. (1935) 660.

99. Service Gas Co., 15 P. U. R. (x.s.) 202 (Pa. 1936); Cabot Gas Corp., 16 P. U. R. (N.s.) 443 (N. Y. 1936) ; Western Natural Gas Co., P. U. R. 1930A 307 (Calif.).

100. N. Y. Times, Jan. 19, 1941, p. D7, col. 1.

101. Industrial Gas Co., P. U. R. 1929 A 516 (Afo.).

102. Lukens Steel Co., 25 P. U. R. (N.s.) 20 (Pa. 1938) ; People's National Gas Co., P. U. R. 1915C 696 (Pa.); Industrial Gas Co., P. U. R. 1929A 516 (MOo.). It has bren argued that a difference of 196 B.tu. between two natural gases represents a new service. Brief for appellants, p. 109, in Louisiana Nevada Transit Co., 142 S. W. (2d) 213 (Ark: 1940). See also Vincent, Natural Gas in California (1939) 21 Asrerrcun Gas Assocantion Proceedings 61.

103. Louisiana Nevada Transit Co., 32 P. U. R. (N.s.) 219 (Arl: 1939). See also 30 P. U. R. (N.s.) 40 (F. P. C. 1939).

104. Míunicipal Gas Co., P. U. R. 1928D 418 (Okla.).

105. Village of Hustisford, 2 P. U. R. (N.S.) 485 (Wis. 1934).

106. Industrial Gas Co., P. U. R. 1929 A 516 (MIo.). 
rates spell the end of exclusive control of the market regardless of claimed theoretical advantages in operating costs, ${ }^{107}$ unless the commission grants time to repent. ${ }^{108}$ When rates are too high, it is no excuse for the continuance of monopoly that consumers might have sought relief by complaint to the commission. ${ }^{109}$ Furthermore, in the comparison of the existent with the proposed rates, the newcomer must offer more than a mere shading in rates to be a successful applicant. ${ }^{110}$ To aid in determining whether the applicant's rates will remain reasonable in the future, the commission relies not only on consumers' testimony, but also on an examination of construction contracts and contracts for supply of the product to be resold. 111

To service and rate considerations, the California Commission added the doctrine of saturation or potential demand.112 Closely associated with the previously mentioned categories of competition, this criterion stresses the advantage of permitting competition in an area where economic expansion has not ceased. Those customers lost by the old company will be compensated for by the securing of new business. ${ }^{113}$ Furthermore, wherever a new utility will aid in expanding the economy of the region or will assist in retaining industry already there, it is a point in its favor. ${ }^{114}$ At the other extreme, the outcome of competition in a static economy may be mutual bankruptcy, particularly if it will mean superfluous facilities. ${ }^{115}$

. Still another consideration is the interest of investors in the existing utility. In this regard, the commissions have split. On the one hand, it is contended

107. State $e x$ rel. Kansas City P. \& L. Co. v. Public Service Comm., 335 Mo. 1248, $76 \mathrm{~S}$. W. (2d) 343 (1934); State ex rel. Electric Co. of Missouri v. Atkinson, 275 Mo. 325, 204 S. W. 897 (1918); Industrial Gas Co., P. U. R. 1929A 516 (Mo.); Truckec River Power Co., P. U. R. $1928 \mathrm{E} 83$ (Calif.) ; Santa Maria G. \& P. Co., 9 Cal. R. C. R. 514 (1916) ; People's Natural Gas Co., P. U. R. $1915 C 696$ (Pa.).

108. City of Yuma, 2 P. U. R. (N.s.) 8 (Ariz. 1933); see cases cited supra note 77. 109. State ex rel. Kansas City P. \& L. Co. v. Public Service Comm., 335 Mo. 248, 76 S. W. (2d) 343 (1934); Western Natural Gas Co., P. U. R. 1930 A 307 (Calif.) (dissent). See Witmer, Consumers' Appeals from Public Service Commission Rate Orders (1941) 8 U. OF CHI. L. Rev. 258.

110. Raytown Chamber of Commerce, 17 Mo. P. S. C. R. 601 (1929) ; Beaver River P. \& L. Co., P. U. R. 1915B 281 (Idaho) ; Oro Electric Corp., 2 Cal. R. C. R. 748 (1913).

111. Kansas Pipe Line \& Gas Co., 30 P. U. R. (N.s.) 321 (F. P. C. 1939) ; Louisiana Nevada Transit Co., 32 P. U. R. (N.s.) 219 (Ark. 1939).

112. Pacific G. \& E. Co., 1 Cal. R. C. R. 203 (1912) ; see cases cited supra note 75.

113. Louisiana Nevada Transit Co., 32 P. U. R. (N.S.) 219 (Ark. 1939). The Federal Trade Commission has warned of the danger of underestimating the increased demand for power caused by national defense expansion in industry. The thrcat of war itself has magnified the importance of duplication of facilities as a means of preserving continuity of service under all circumstances. See N. Y. Times, Mar. 2, 1941, p. L18, col. 1.

114. Ibid.; Idaho L. \& P. Co., P. U. R. 1915A 2 (Idaho).

115. Callicoon Independent Electric Co., P. U. R. 1919C 672 (N. Y.); Midvalley Power Co., P. U. R. 1916A 959 (Pa.); Gray, loc. cit. supra note 38. 
that since the existing utility made expenditures in the belief that it held an exclusive privilege, the stockholders should be protected regardless of the inferior service. 116 On the other hand, guided by the doctrine that the protection of the existing utility is incidental to the welfare of the consumers, some commissions have said that investors undertook the hazard of financial loss. ${ }^{117}$ The California Commission, for instance, has declared that it feels no obligation to protect the investment of a utility which is not doing its full duty to the public. ${ }^{118}$ Wisconsin likewise refused to shield investors where the utility indulged in extravagant expenditures. ${ }^{110}$ Of course, investors may not be materially injured where the competition is restricted, ${ }^{120}$ or where the new company will purchase the old one for a fair value. ${ }^{121}$

Still another aspect of the position of the investor concerns the securing of new capital. It is stated that in addition to the possible direct injury to present security holders, loss of a monopoly position may seriously curtail the ability of the old company to float new security issues. The common objection is that competition introduces a new risk of reduced earnings to the point where it becomes more expensive to attract capital in the future. 1202 Actually, however, assuming intelligent commission regulations, profits may not be critically reduced by competition, for the elasticity of demand enables greater revenue to flow from lower rates. Moreover, it appears that the sufficient-return-to-attract-capital thesis has been overworked in the case of public utilities. ${ }^{123}$ It is questionable to pursue a policy of investment protection which may undermine in utilities one of the most creative driving forces in capitalism - risk-taking. ${ }^{124}$

The degree of risk assumed by either one of two competitors is likely to vary with their relative financial strength. But to predict precisely the results of financial disparity is exceedingly difficult, because both a weak and a powerful company may pursue price policies designed to enlarge the risks taken by the other. Although there is some contrary authority, ${ }^{125}$ it has been generally held that in comparing financial resources the largest utility is not necessarily entitled to prevent competition from a smaller

116. Re Tootell, P. U: R. 1927A 155 (N. H.); Independence Natural Gas Co., P. U. R. 1923D 433 (Mo.); Wilkes-Barre Light Co., P. U. R. 1917C 906 (Pa.).

117. Re Eyer, P. U. R. 1926A 140 (Mo.) ; Green L. \& P. Co., 10 Mfo. P. S. C. R. 58 (1920).

118. Truckee River Power Co., P. U. R. 1928E 83 (Calif.).

119. Village of Hustisford, 2 P. U. R. (N.s.) 485 (Wis. 1934).

120. Raystown Water Power Co., P. U. R. $1915 \mathrm{~B} 862$ (Pa.).

121. Turner L. \& P. Co., P. U. R. 1916A 418 (Me.).

122. BenLiNG, op. cit. supra note 1, at 42; JoNES AND BIGEAss, op. cit. sespre note 3, at $93-97$.

123. BeHLING, op. cit. supra note 1 at 42.

124. 2 Fairchind, Furniss ANd Buck, Elearextary Ecososics (4th ed. 1939) 195201.

125. Re Western Natural Gas Co., P. U. R. 1930A 307 (Calif.). 
company. ${ }^{120}$ Even assuming that a commission has decided what plane of competition it prefers to promote, the weaknesses of prophesying the future of rates and service based on comparative financial strength are serious enough to make a commission doubt its fears of the result. Generally, one who seeks entry must indicate financial backing commensurate with the undertaking. ${ }^{127}$ There is a division of opinion, however, as to whether the specific financial plan need be approved.128 Furthermore, where funds are to be obtained from the Reconstruction Finance Corporation, an unconditional certificate will not be issued until the Government agency has made its separate commitment. ${ }^{120}$

Another operative factor which the commissions consider is public opinion. Expressions of a preference for a particular company bear weight ; $^{\mathbf{1 3 0}}$ and the regulatory bodies are not indifferent to complaints of consumers and to poor public relations.131 On the other hand, absence of complaints against the rate of the existing company for eight years has not been ignored when competition threatened. ${ }^{132}$ Public opinion, however, also includes the expression of special pressure groups to keep out competing services. Both natural gas and hydro-electric power run into bitter opposition from coal, labor, and railroad interests, especially in the coal producing states. ${ }^{133}$ But the commissions, aware of the dangers of erecting artificial trade barriers, ${ }^{134}$ have been reluctant to impede the entrance of cheaper services. ${ }^{135}$ And where the avowed policy of the state is to prevent wastage of natural gas, competition has been urged as a means to achieve more complete utilization. ${ }^{130}$

If a revaluation and analysis of utility competition leads to a less automatic and more reflective consideration of competition, it will be one step in the direction of improved commission regulation. Naturally, in practice, the various specific factors will be considered in their totality of relations rather

126. Union Public Service Co. v. Corporation Comm., 140 Kan. 722, 37 P. (2d) 1010 (1934).

127. Kansas Pipe Line \& Gas Co., 30 P. U. R. (N.s.) 321 (F. P. C. 1939) ; Jackson County L. H. \& P. Co., 16 P. U. R. (N.s.) 244 (Mo. 1936) ; Colorado Gas \& Oil Line Co., P. U. R. 1925A 499 (Colo.).

128. Louisiana Nevada Transit Co., 32 P. U. R. (N.s.) 219 (Ark. 1939) ; Industrial Gas Co., P. U. R. 1929A 516 (Mo.).

129. Kansas Pipe Line \& Gas Co., 30 P. U. R. (N.s.) 321 (F. P. C. 1939).

130. State $e x$ rel. Kansas City P. \& L. Co. v. Public Service Comm., 335 Mo. 1248, 76 S. W. (2d) 343 (1934); see cases cited supra note 128.

131. Re Call, P. U. R. $1932 \mathrm{D} 387$ (Wyo.) ; Municipal Gas Co., P. U. R. 1928D 418 (Okla.); Truckee River Power Co., P. U. R. 1928E 83 (Calif.).

132. Re Western Gas Co., P. U. R. 1930A 307 (Calif.).

133. North Dakota Consumers Gas Co., 30 P. U. R. (N.s.) 9 (N. D. 1939) ; Kansas Pipe Line \& Gas Co., 30 P. U. R. (N.s.) 321 (F. P. C. 1939); Lukens Steel Co., 25 P. U. R. (N.S.) 20 (Pa. 1938) ; Cabot Gas Corp., 16 P. U. R. (N.S.) 443 (N. Y. 1936); West Virginia Power \& Transmission Co., P. U. R. 1930D 225 (W. Va.).

134. Rogers, Capitalism in Crisis (1938) c. 7.

135. See cases cited stpra note 133.

136. Western Gas Co., P. U. R. 1930A 307 (Calif.) (dissent). 
than as abstracted entities. Whether "natural" monopoly is preserved or competition is admitted will depend largely on the particular facts as well as on commission policy. Perhaps when state regulation of private monopoly can more nearly approach the benefits of competition than at present, direct competition may be superfluous. That day has not yet arrived. In the meantime, the best service to the public will be rendered by commissions which, in passing on the desirability of competition, have the courage and honesty to include as a "factor" their own strength or impotency in obtaining lower rates and better service. Unthinking devotion to an early commission holding in favor of regulated monopoly may not only penalize the consumers of one area, but the removal of the threat of competition also destroys the powerful incentive to improvement throughout a state. It is true that competition may only be a temporary curative pending the future existence of enlightened utility management, greatly improved commission regulation, or public ownership. But the remoteness of any or all of these potential remedies demands that serious consideration be accorded regulated competition. 